\title{
PENGEMBANGAN WISATA DI KAMPUNG WAYANG KEPUHSARI, KECAMATAN MANYARAN, KABUPATEN WONOGIRI BERBASIS ANALISIS SWOT
}

\author{
Lilyk Eka Suranny \\ Peneliti Bappeda dan Litbang Kabupaten Wonogiri \\ Email: lilik_fd@yahoo.com
}

\begin{abstract}
Abstrak. Penelitian ini bertujuan untuk menyusun strategi pengembangan wisata pada Kampung Wayang di Desa Kepuhsari, Kecamatan Manyaran, Kabupaten Wonogiri berdasarkan analisis SWOT. Metode penelitian yang digunakan adalah deskriptif kualitatif. Pendekatan kualitatif diperoleh dalam bentuk data primer dan data sekunder. Teknik pengumpulan data menggunakan metode observasi, wawancara, studi dokumen dan studi pustaka. Analisis data yang digunakan adalah analisis SWOT (Strenght, Weakness, Opportunities, Threats). Berdasarkan hasil dari analisis SWOT alternatif strategi dalam pengembangan wisata di Kampung Wayang antara lain Pengembangan Kampung Wayang sebagai tempat wisata minat khusus (wisata budaya, wisata pendidikan); Perbaikan aksesibilitas daerah wisata; Meningkatkan Sumber daya manusia pelaku usaha wisata; Penggalangan dana mandiri, pemerintah, dan investasi swasta untuk pengembangan wisata; Promosi wisata yang kontinyu; meningkatkan daya saing obyek wisata yang berkualitas dan unik serta peningkatan manajemen pengelolaan wisata.
\end{abstract}

Kata kunci: strategi, pengembangan wisata, kampung wayang

Abstract. This study aims to compile a tourism development strategy in Wayang Village Kepuhsari, Manyaran District, Wonogiri Regency based on SWOT analysis. Qualitative approach is obtained in the form of primary data and secondary data. Technique of collecting data using observation method, interview, document study and literature study. Data analysis used is SWOT analysis (Strength, Weakness, Opportunities, Threats). Based on the results of several alternative research strategies in the development of tourism in Wayang Village among others Development of Wayang Village as a special interest tourism (cultural tourism, educational tour); Improved accessibility of tourist areas; Improve human resources of tourism business actors; Self-fund raising, government and private investment for tourism development; continuous tourism promotion; Increasing the competitiveness of a quality and unique tourism object; and improved tourism management.

Keywords: strategy, tourism development, wayang village

\section{PENDAHULUAN}

Pembangunan ekonomi daerah adalah suatu proses dimana pemerintah daerah dan masyarakat mengelola sumberdaya yang ada dan membentuk suatu pola kemitraan antara pemerintah daerah dengan sektor swasta untuk menciptakan suatu lapangan kerja baru dan merangsang perkembangan kegiatan ekonomi (pertumbuhan ekonomi) dalam wilayah tersebut. Oleh karena itu, pemerintah daerah beserta partisipasi masyarakatnya dan dengan sumber daya yang ada harus mampu menaksir potensi sumber daya yang diperlukan untuk merancang dan membangun perekonomian daerah untuk meningkatkan kualitas hidup seluruh masyarakat pada daerah tersebut (Arsyad, 
1999). Optimalisasi pencapaian program pembangunan tidak terlepas dari kejelian pemerintah daerah dalam memanfaatkan potensi sumberdaya yang ada. Berbagai potensi yang ada di daerah baik berupa sumberdaya alam maupun sumberdaya manusia dimaksimalkan pemanfaatannya guna peningkatan ekonomi masyarakat.

Kegiatan pariwisata merupakan salah satu potensi yang dapat diharapkan dapat memberikan kontribusi yang cukup besar terhadap perekonomian daerah. Usaha pengembangan pariwisata tertuang dalam Undang-undang No.10 tahun 2009, menyebutkan bahwa keberadaan obyek wisata pada suatu daerah akan sangat menguntungkan, diantaranya dapat meningkatkan Pendapatan Asli Daerah (PAD), meningkatkan taraf hidup masyarakat, meningkatkan rasa cinta lingkungan, serta melestarikan alam dan budaya setempat. Dengan adanya otonomi daerah maka sumber terbesar keuangan daerah dapat berasal dari PAD sehingga setiap daerah diharapkan dapat meningkatkan kemandirian dan daya saing daerahnya.

Salah satu obyek wisata yang mulai dikembangkan di Kabupaten Wonogiri adalah Kampung Wayang yang potensi utamanya pada sektor budaya yakni kesenian tatah sungging wayang atau seni pembuatan wayang kulit. Seni kerajinan tatah sungging oleh masyarakat di Desa Kepuhsari tersebut merupakan warisan secara turun temurun dari leluhur. Kerajinan wayang oleh masyarakat setempat tidak hanya dijadikan produk budaya, tetapi juga sebagai produk ekonomi. Kegiatan pembuatan wayang kulit ini dijadikan sebagai mata pencaharian penduduk di Desa Kepuhsari, adapula yang menjadikannya sebagai pekerjaan sampingan saja. Dalam pengerjaannya mereka bekerja sendiri namun ada juga yang bergabung dengan pengrajin yang telah memiliki sanggar. Tercatat hingga tahun 2015 di Desa Kepuhsari ini sudah memiliki 135 kepala keluarga yang melakoni usaha sebagai pengrajin wayang kulit. Oleh karena itu Desa Kepuhsari dijuluki sebagai Kampung Wayang. Untuk tetap menjaga eksistensi keberadaan wayang kulit di Desa Kepuhsari, masyarakat disana menggunakan kesenian wayang sebagai hiburan ketika ada acara kampung/hajatan. Kebiasaan ini memperkuat citra Desa Kepuhsari sebagai Kampung Wayang. Cirikhas tersebut merupakan keunikan desa yang dapat dijadikan sebagai potensi wisata. Hal ini sejalan dengan pengembangan pariwisata pedesaan yang menjadikan kawasan pedesaan yang memiliki potensi karakteristik khusus (cirikhas) menjadi daerah tujuan wisata.

Seni tatah sungging ini dapat dijadikan sebagai potensi wisata yakni dapat berupa wisata pendidikan yaitu mengajari wisatawan cara membuat wayang kulit. Selain kesenian tatah sungging, potensi wisata lainnya yang dapat dikembangkan di Desa Kepuhsari adalah wisata alam berupa air terjun “ Banyu Nibo". Beberapa potensi yang ada di Kampung Wayang ini dapat dikembangkan menjadi destinasi wisata yang menguntungkan bagi masyarakat di Kampung Wayang khususnya ataupun pemerintah daerah sebagai salah satu sumber Pendapatan Asli Daerah (PAD). Saat ini potensi wisata yang ada di Kampung Wayang belum dimanfaatkan secara optimal oleh masyarakat untuk dikembangkan menjadi daerah tujuan wisata. Tujuan dari penelitian ini adalah

a. Mengetahui kondisi eksisting Kampung wayang yang dapat 
dikembangkan menjadi daerah tujuan wisata

b. Menyusun strategi pengembangan wisata pada Kampung Wayang Desa Kepuhsari, Kecamatan Manyaran, Kabupaten Wonogiri melalui analisis SWOT.

\section{TINJAUAN PUSTAKA \\ Konsep Strategi}

Menurut Stanton dalam Amirullah (2004) menyatakan strategi sebagai suatu rencana dasar yang luas sebagai suatu tindakan organisasi untuk mencapai tujuan. Rencana dalam mencapai tujuan tersebut sesuai dengan lingkungan eksternal dan internal perusahaan. Begitu juga dengan Christensen dalam Rangkuti (2005) menyatakan bahwa strategi merupakan suatu alat untuk mencapai keunggulan bersaing. Porter dalam Rangkuti (2005) mengungkapkan bahwa strategi merupakan alat yang sangat penting untuk mencapai keunggulan bersaing. Menurut Chandler dalam Rangkuti (2005) menyatakan bahwa strategi merupakan alat untuk mencapai tujuan perusahaan dalam kaitannya dengan tujuan jangka panjang, program tindak lanjut serta prioritas alokasi. Dari beberapa tinjauan diatas maka pengertian strategi yang sesuai dengan penelitian ini adalah suatu kesatuan rencana dalam bentuk program-program terpadu dan menyeluruh untuk mencapai tujuan yang diharapkan.

\section{Konsep Pengembangan}

Menurut

Suwantoro

(2004)

menyatakan bahwa pengembangan bertujuan untuk mengembangkan produk dan pelayanan yang berkualitas, seimbang dan bertahap. Sedangkan Poerwadarminta (2002), menyatakan pengembangan lebih menekankan kepada suatu proses atau suatu cara menjadikan sesuatu menjadi lebih maju, baik dan berguna.

Berdasarkan konsep diatas maka strategi pengembangan wisata merupakan suatu rencana/program terpadu yang dipergunakan untuk memajukan, memperbaiki dan meningkatkan kondisi kepariwisataan suatu objek dan daya tarik wisata sehingga dikunjungi wisatawan serta mampu memberikan manfaat bagi masyarakat disekitar objek dan daya tarik wisata maupun bagi pemerintah.

\section{Pembangunan pariwisata}

Pembangunan pariwisata yang berhasil adalah pembangunan pariwisata yang dilakukan bersama termasuk "membangun bersama masyarakat" sehingga pembangunan pariwisata dapat memberikan keuntungan secara ekonomi, sosial, budaya setempat. Tujuan pariwisata yang melibatkan masyarakat, diantaranya yaitu: 1). Memberdayakan masyarakat melalui pembangunan pariwisata, 2). Meningkatkan peran dan partisipasi masyarakat agar dapat memperoleh keuntungan ekonomi, sosial maupun budaya dari pembangunan pariwisata, 3). Memberikan kesempatan yang seimbang kepada semua anggota masyarakat baik laki-laki maupun perempuan. Oleh karena itu salah satu pendekatan yang dapat digunakan untuk pengembangan pariwisata berbasis masyarakat adalah pendekatan partisipatif. Pengembangan pariwisata berbasis masyarakat ini dinamakan Community Based Tourism (Demartoto, 2009).

\section{Analisis SWOT}

Analisis SWOT dalam bidang pariwisata dapat dimanfaatkan untuk merumuskan arahan dan skenario pengembangan wisata baik secara mikro sampai skala makro yang saling berhubungan, artinya SWOT dapat 
merumuskan secara rasional dan berurutan sesuai dengan tujuan keperluannya sebagai berikut:

Menggambarkan permasalahan yang perlu diindikasikan untuk suatu keperluan tertentu,

$>$ Menganalisis hubungan antar issue,

$>$ Memberikan skenario dan arahan keadaan sekarang dan masa datang yang akan dituju.

Analisis SWOT sering diartikan sebagai alat identifikasi berbagai faktor secara sistematis untuk merumuskan strategi. Analisis SWOT dilakukan berdasarkan logika yang dapat memaksimalkan potensi dan peluang namun secara bersamaan dapat meminimalisasi kendala dan ancaman sehingga akan memberikan output berupa target atau perlakuan untuk mencapai tujuan. Tabel analisis SWOT dapat ditampilkan sebagai berikut:

Tabel 1. Metode Analisis SWOT

\begin{tabular}{|l|l|c|c|}
\hline Faktor Penentu & & \multicolumn{2}{|c|}{ Faktor Internal } \\
\cline { 3 - 4 } & & $\begin{array}{l}\text { Kekuatan } \\
\text { (Strenght) }\end{array}$ & $\begin{array}{l}\text { Kelemahan } \\
\text { (Weakness) }\end{array}$ \\
\hline Faktor Eksternal & Peluang (Opportunities) & S-O & W-O \\
\cline { 2 - 4 } & Ancaman (Threats) & S-T & W-T \\
\hline
\end{tabular}

Sumber: Salusu, 2003

Dari hasil analisis SWOT akan dihasilkan beberapa strategi (Salusu, 2003) antara lain:

1. Strategi S-O untuk menarik keuntungan dari peluang yang tersedia dari lingkungan eksternal.

2. Strategi W-O bertujuan untuk memperbaiki kelemahan internal dengan memanfaatkan peluang dari lingkungan eksternal.

3. Strategi S-T bertujuan untuk memperkecil dampak yang akan terjadi dari lingkungan eksternal.

4. Strategi W-T bertujuan untuk memperkuat dari dalam usaha untuk memperkecil kelemahan internal dengan memperkecil tantangan eksternal.

\section{METODE PENELITIAN}

Penelitian ini dilaksanakan di Kampung Wayang Desa Kepuhsari, Kecamatan Manyaran, Kabupaten
Wonogiri yang dimulai pada bulan Mei sampai dengan September 2016. Metode penelitian yang digunakan adalah deskriptif kualitatif untuk mengetahui kondisi eksisting dan potensi yang ada di Kampung Wayang yang dapat dikembangkan menjadi daerah tujuan wisata. Data yang digunakan adalah data primer dan data sekunder. Teknik pengumpulan data menggunakan metode observasi, wawancara, studi dokumen dan studi pustaka. Observasi dilakukan dengan mendatangi lokasi penelitian yakni di Kampung Wayang untuk mendapatkan data dengan melihat secara langsung mengenai potensi yang ada di Kampung Wayang yang dapat diangkat sebagai daerah wisata. Wawancara dilakukan dengan bertanya langsung pada narasumber yang mengetahui kondisi di Kampung Wayang yakni Kepala Dinas Pariwisata Kabupaten Wonogiri, Kepala Desa Kepuhsari, Ketua 
pokdarwis/anggota, dan Pengrajin tatahsungging/lukis kaca serta tokoh masyarakat setempat. Studi dokumen melalui pengumpulan data yang diperoleh langsung di lokasi penelitian yaitu foto dokumentasi dan beberapa dokumen pendukung yakni diperoleh dari kelompok Sadar wisata "Tetuko" di kampung wayang. Studi pustaka yang didapatkan dari beberapa sumber terkait penelitian yang mendukung.

Untuk penyusunan konsep pengembangan wisata di Kampung Wayang Kepuhsari digunakan analisis SWOT yaitu menganalisis kekuatan, kelemahan, kesempatan (peluang) dan hambatan (ancaman) yang ada. Kekuatan dan kelemahan lebih banyak terjadi di lingkungan dalam (internal) sedangkan peluang dan ancaman lebih banyak terjadi di lingkungan luar (Rangkuti dalam Arsyadha, 2002). Analisis SWOT sering diartikan sebagai alat identifikasi berbagai faktor secara sistematis untuk merumuskan strategi. Analisis SWOT dilakukan berdasarkan logika yang dapat memaksimalkan potensi dan peluang namun secara bersamaan dapat meminimalisasi kendala dan ancaman sehingga akan memberikan output berupa target atau perlakuan untuk mencapai tujuan.

\section{HASIL DAN PEMBAHASAN}

\subsection{Analisis Kondisi Eksisting} Kampung Wayang Desa Kepuhsari

Tujuan dari analisis ini adalah untuk mengetahui kondisi eksisting kawasan Kampung Wayang sehingga dapat diketahui arahan pengembangannya. Metode analisis yang digunakan adalah teknik analisis SWOT, yaitu analisis dengan memperhatikan potensi berupa kekuatan dan peluang tanpa mengabaikan kelemahan dan ancaman sebagai acuan usaha pengembangannya lebih lanjut. Dengan mengetahui kekuatan dan peluang yang dimiliki sebagai faktor pendukung usaha pengembangan kegiatan wisata serta dengan memperhatikan kelemahan dan ancaman yang menghambat usaha pengembangan tersebut diharapkan langkah atau usaha pengembangan yang direncanakan merupakan rencana yang tepat guna dan berkelanjutan.

\section{a. Analisis Variabel internal}

Input analisis variabel internal ini adalah faktor-faktor yang menjadi kekuatan dan kelemahan yang berasal dari lingkungan dalamnya.

\section{Kondisi eksisting berdasarkan kekuatan yang dimiliki}

1. Kampung Wayang Kepuhsari memiliki kondisi eksisting yang menjadi kekuatan dalam usaha pengembangan wisata yaitu keindahan alam, potensi sumberdaya manusia dan potensi sumberdaya budaya. Potensi keindahan air terjun "Banyu Nibo" serta keadaan wilayah yang berupa lahan pertanian dan pegunungan ini dapat berpotensi dijadikan wisata alam maupun wisata pendidikan. Wisata alam yang memperlihatkan keindahan air terjun dan lingkungan sekitarnya yang masih alami serta wisata pendidikan pertanian yang mengajarkan para wisatawan bercocok tanam/budidaya pertanian. Potensi sumberdaya manusia dapat dilihat dari ketrampilan yang dimiliki masyarakatnya yaitu seni tatah sungging (seni kerajinan membuat wayang kulit). Ketrampilan tatah sungging bagi masyarakat di Desa Kepuhsari ini telah mendarah daging dan diturunkan secara turuntemurun. Tatah sungging oleh 
masyarakat Desa Kepuhsari ini dijadikan sebagai mata pencaharian pokok ataupun sampingan karena umumnya masyarakatnya adalah daya tarik wisata.

2. Kekuatan lain yang dimiliki oleh Kampung Wayang Kepuhsari adalah keramah tamahan masyarakatnya dalam memberikan pelayanan kepada para pengunjung. Tingkat kepuasan dari pengunjung dapat dinilai salah satunya dari pelayanan yang didapatkan saat melakukan kunjungan wisata. Jika mereka merasa puas dengan pelayanan pada sebuah destinasi wisata kemungkinan besar pengunjung akan kembali ke dearah wisata tersebut. Hal ini akan sangat menguntungkan bagi daerah wisata. Hal tersebut sesuai dengan pernyataan Tjiptono (2002) bahwa apabila jasa yang diterima atau dirasakan (perceived service) sesuai dengan yang diharapkan (expected service), maka kualitas jasa dipersepsikan baik dan memuaskan. Jika jasa yang diterima melampaui harapan pelanggan, maka kualitas jasa dipersepsikan sebagai kualitas yang ideal. Sebaiknya jika jasa yang diterima lebih rendah daripada harapan pelanggan, maka kualitas jasa yang dipersepsikan buruk. Kepuasan wisatawan inilah yang sangat perlu diperhatikan ketika merencanakan paket wisata karena merupakan landasan wisatawan untuk kembali lagi atau tidak ke suatu destinasi wisata.

Kondisi Eksisting Kampung Wayang berdasarkan kelemahan yang dimiliki

Permasalahan yang ada di Desa Kepuhsari dapat digolongkan pada beberapa kriteria, antara lain: petani. Ini menjadi keuntungan tersendiri apabila dapat mengemas ketrampilan tatah sungging menjadi

1. Prasarana

Infrastruktur jalan kurang memenuhi syarat karena beberapa jalan desa belum diaspal sehingga perlu ada peningkatan pengaspalan jalan-jalan menuju desa wisata.

> Belum ada gapura yang dapat dijadikan identitas desa sebagai kampung wayang.

Show Room untuk memajang hasil kerajinan wayang belum ada, selama ini masih bergabung dengan sanggar kerajinan;

2. Kelembagaan

Desa Kepuhsari telah mempunyai Kelompok Sadar Wisata (Pokdarwis) "Tetuko" namun pada pelaksanaannya belum bisa mewadahi berbagai elemen masyarakat pendukung pariwisata. Hal ini karena keterbatasan Sumberdaya Manusia dan aspek kelembagaan yang masih perlu ditingkatkan (administrasi, profil kelembagaan, promosi, kepengurusan, pembagian tugas dan wewenang, dan permodalan).

Sebagian masyarakat Desa Kepuhsari belum dapat memahami pentingnya kelembagaan, bahkan ada yang berfikir negatif bahwa kelembagaan Pokdarwis hanya untuk kesejahteraan kelompok kepentingan tertentu (pengurus) saja.

3. Sumber Daya Manusia

SDM pengelola wisata yang masih rendah diantaranya kurang menguasai Bahasa Inggris sedangkan wisatawan yang datang 
berkunjung tidak hanya dari lokal saja namun juga wisatawan mancanegara.

Masih rendahnya kegiatan promosi wisata yang dilakukan oleh pengelola di Kampung Wayang Kepuhsari karena tingkat pengetahuan yang masih tergolong minim dalam kegiatan promosi wisata.

\section{b. Rumusan Variabel Internal}

Hasil analisis variabel internal yaitu kekuatan dan kelemahan yang dimiliki Kampung Wayang Kepuhsari sebagai faktor pendukung usaha pengembangan desa wisata dapat dirumuskan sebagai berikut:

Tabel 2. Rumusan Variabel Internal

\begin{tabular}{|l|l|l|}
\hline No & \multicolumn{1}{|c|}{ Faktor Penentu } & \multicolumn{1}{|c|}{ Keterangan } \\
\hline 1. & Kekuatan & $\begin{array}{l}\text { Potensi sumberdaya alam, sumberdaya } \\
\text { manusia dan sumberdaya budaya di } \\
\text { Kampung Wayang Kepuhsari }\end{array}$ \\
\cline { 3 - 4 } & & $\begin{array}{l}\text { Keramahtamahan masyarakat kepada } \\
\text { pengunjung }\end{array}$ \\
\cline { 3 - 4 } & Kelemahan & $\begin{array}{l}\text { Aksesibilitas daerah wisata yang kurang } \\
\text { memadai }\end{array}$ \\
\cline { 3 - 4 } & & $\begin{array}{l}\text { Minimnya peran masyarakat dalam } \\
\text { kelembagaan }\end{array}$ \\
\cline { 3 - 4 } & & SDM pemandu wisata yang masih lemah \\
\cline { 3 - 4 } & &
\end{tabular}

Sumber: Analisis data primer, 2016

\section{c. Analisis Variabel Eksternal}

Input analisis variabel eksternal ini adalah faktor-faktor yang merupakan kesempatan (peluang) dan ancaman yang ada dan terjadi atau berasal dari luar lingkungannya.

\section{Kondisi Eksisting Kampung Wayang} Berdasarkan Peluang Yang ada

Trend Pengembangan wisata minat khusus (Wisata pendidikan)

Dengan kebutuhan yang sangat komplek seperti sekarang ini menuntut masyarakat untuk dapat meluangkan waktu mereka guna berwisata. Kegiatan berwisata masyarakat juga dapat dilakukan sambil belajar baik atas alam, budaya, adat istiadat, lingkungan, sosial, dan aspek pendukung lainnya. Potensi wisata di Kampung Wayang ini dapat dimungkinkan dapat dikembangkan menjadi wisata pendidikan, diantaranya wisata pendidikan pembuatan wayang ataupun wisata pendidikan pertanian.

Potensi wisatawan lokal Wonogiri di tingkat pelajar yang besar

Potensi wisatawan lokal dari pihak sekolah lokal di Kabupaten Wonogiri saja ada 800 sekolah SD/sederajat dengan 7.761 guru dan 82.868 murid. Sementara jumlah SLTP/sederajat ada 141 sekolah dengan 3.784 guru dan 43.236 murid; SLTA/sederajat ada 
117 sekolah dengan 3.042 guru dan 30.329 murid (Wonogiri Dalam Angka, 2014). Apabila kita dapat menarik minat wisatawan dari tingkat sekolah lokal Wonogiri saja akan sangat besar dampak positif dari peningkatan ekonomi masyarakat.

$>$ Adanya kebijakan pemerintah daerah untuk mengembangkan pariwisata daerah

Pemerintah daerah mempunyai perananan yang penting dalam pengembangan sektor priwisata. Apalagi di era otonomi daerah seperti saat ini, pariwisata diharapkan mampu memberikan sumbangan yang besar bagi peningkatan pendapatan daerah. Pengembangan pariwisata diharapkan dapat meningkatkan taraf hidup masyarakat di kawasan wisata.

\section{Kondisi Eksisting Kampung Wayang} Berdasarkan Ancaman Yang ada

$>$ Keterbatasan dana pengembangan

Dalam upaya pengembangan pariwisata salah satu kendala yang dihadapi adalah keterbatasan dana pengembangan. Hal tersebut menyebabkan upaya pengembangan pariwisata yang dilakukan tidak optimal. Keterbatasan dana yang diterima untuk mengelola obyek wisata dalam pembangunan potensi dan pemeliharaan sarana dan prasarana obyek wisata. Misalnya saja untuk perbaikan sarana dan prasarana harus menunggu dana dari pemerintah daerah belum lagi dana untuk melakukan inovasi pastilah akan menunggu dengan waktu yang lebih lama. Jika dana dari pemerintah daerah belum cair maka perawatan dan perbaikan sarana dan prasarana belum dapat dilakukan.

Terdapat tempat wisata lain yang menjadi pesaing

Daya saing pariwisata mengandung arti bahwa produk pariwisata yang dijual hendaknya produk yang sesuai dengan atribut yang dituntut konsumen atau produk yang dipersepsikan bernilai tinggi oleh konsumen. Saat ini banyak tempat wisata sejenis yang menampilkan/menyuguhkan wisata minat khusus bagi pengunjung. Untuk mengatasi persaingan dengan daerah wisata lain maka suatu destinasi wisata harus dapat menampilkan cirikhas yang menjadi potensi daerah setempat.

Kondisi perekonomian bangsa yang tidak stabil

Keadaan ekonomi suatu negara juga mempegaruhi kunjungan wisatawan pada suatu destinasi wisata. Pada saat kondisi ekonomi baik maka kunjungan wisatawan dapat mengalami kenaikan sedangkan saat ekonomi lesu maka dimungkinan kunjungan wisatawan akan menurun.

\section{a. Rumusan Variabel Eksternal}

Hasil analisis variabel eksternal yaitu peluang dan ancaman yang dimiliki Kampung Wayang Kepuhsari sebagai faktor pendukung usaha pengembangan desa wisata dapat dirumuskan sebagai berikut 
Tabel 3. Rumusan Variabel Eksternal

\begin{tabular}{|l|l|l|}
\hline \multicolumn{1}{|c|}{ No } & \multicolumn{1}{|c|}{ Faktor Penentu } & \multicolumn{1}{c|}{ Keterangan } \\
\hline 1. & Peluang (Opportunities) & $\begin{array}{l}\text { Trend kunjungan wisatawan lebih memilih } \\
\text { wisata minat khusus }\end{array}$ \\
\cline { 3 - 4 } & & $\begin{array}{l}\text { Potensi wisatawan lokal Wonogiri tingkat } \\
\text { pelajar yang besar }\end{array}$ \\
\cline { 3 - 4 } & Hambatan (Threats) & $\begin{array}{l}\text { Adanya kebijakan pemerintah daerah untuk } \\
\text { mengembangkan pariwisata daerah }\end{array}$ \\
\hline 2 & & $\begin{array}{l}\text { Keterbatasan dana pengembangan wisata } \\
\text { perdapat tempat wisata lain yang menjadi }\end{array}$ \\
\cline { 3 - 4 } & $\begin{array}{l}\text { Kondisi perekonomian bangsa yang tidak } \\
\text { stabil }\end{array}$ \\
\hline
\end{tabular}

Sumber: Analisis data primer, 2016

\subsection{Kondisi Eksisting Kampung Wayang Berdasarkan Analisis SWOT}

Hasil analisis variabel eksternal dan variabel internal diatas telah menunjukkan kondisi eksisting pada Kampung Wayang Desa Kepuhsari. Kondisi eksisting Kampung Wayang Kepuhsari dapat dijadikan salah satu dasar pertimbangan usaha pengembangan kawasan wisata yang dapat digunakan sebagai acuan untuk mencapai tujuan dengan cara memaksimalkan potensi dan peluang namun secara bersamaan dapat meminimalisasi kendala dan ancaman. Rumusan dasar pengembangan kawasan wisata Kampung Wayang Kepuhsari berdasarkan kondisi eksisting terdiri dari strategi S-O (Strenght - Opportunities) untuk menarik keuntungan dari peluang yang tersedia dalam lingkungan eksternal kawasan wisata Kampung Wayang Kepuhsari, Strategi W - O (Weakness Opportunities) yang bertujuan untuk memperbaiki kelemahan internal dengan memanfaatkan peluang dari lingkungan eksternal kawasan wisata Kampung Wayang Kepuhsari, Strategi S - T (Strenght- Threats) untuk memperkecil dampak yang akan terjadi dari lingkungan eksternal kawasan wisata Kampung Wayang Kepuhsari, dan strategi W - T (Weakness - Threats) untuk memperkuat dari dalam usaha untuk memperkecil kelemahan internal kawasan wisata Kampung Wayang Kepuhsari dan mengurangi tantangan eksternalnya. Strategi-strategi tersebut dapat dilihat pada tabel 4. 
Tabel 4. Strategi Berdasarkan Kondisi Eksisting Dari Analisis SWOT

\begin{tabular}{|c|c|c|}
\hline E F E & $\begin{aligned} & \text { STRENGTH (S) } \\
& \text { Potensi Sumberdaya } \\
& \text { Alam, sumberdaya } \\
& \text { manusia dan } \\
& \text { sumberdaya budaya } \\
& \text { di Kampung wayang } \\
& \text { Kepuhsari } \\
& \text { * } \\
& \text { Keramah tamahan } \\
& \text { masyarakat kepada } \\
& \text { pengunjung }\end{aligned}$ & $\begin{array}{l}\text { WEAKNESSES }(\mathrm{W}) \\
\text { \# } \text { Aksesibilitas daerah } \\
\text { wisata yang kurang } \\
\text { memadai } \\
\text { \# Minimnya peran } \\
\text { masyarakat dalam } \\
\text { kelembagaan } \\
\text { pariwisata } \\
\text { \# SDM pemandu wisata } \\
\text { yang masih lemah } \\
\text { \# Kurangnya promosi } \\
\text { wisata }\end{array}$ \\
\hline $\begin{aligned} & \text { OPPORTUNITIES } \\
&(\mathrm{O}) \\
& * \text { Trend kunjungan } \\
& \text { wisatawan lebih } \\
& \text { memilih wisata } \text { minat khusus } \\
& * \text { Potensi wisatawan } \\
& \text { lokal Wonogiri } \\
& \text { tingkat pelajar yang } \\
& \text { besar } \\
& * \text { Adanya kebijakan } \\
& \text { pemerintah daerah } \\
& \text { untuk } \\
& \text { mengembangkan } \\
& \text { pariwisata daerah }\end{aligned}$ & $\begin{aligned} & \text { Strategi S-O } \\
\checkmark & \text { Pengembangan } \\
& \text { Kampung wayang } \\
& \text { sebagai tempat wisata } \\
& \text { minat khusus (wisata } \\
& \text { budaya, wisata } \\
& \text { pendidikan) } \\
\checkmark & \text { Pengembangan Paket } \\
& \text { wisata pendidikan } \\
& \text { yang efisien }\end{aligned}$ & $\begin{aligned} & \text { Strategi W-O } \\
& \checkmark \quad \text { Perbaikan } \\
& \text { aksesibilitas daerah } \\
& \text { wisata (jalan dan } \\
& \text { Sarana prasarana } \\
& \text { pendukung lainnya) } \\
& \checkmark \quad \text { Meningkatkan SDM } \\
& \text { pelaku usaha wisata } \\
& \text { (pelatihan pemadu } \\
& \text { wisata, peran } \\
& \text { masyarakat dalam } \\
& \text { kelembagaan). } \\
& \checkmark \text { Promosi wisata yang } \\
& \text { kontinyu }\end{aligned}$ \\
\hline $\begin{aligned} & \text { THREATS }(\mathrm{T}) \\
& \text { Keterbatasan dana } \\
& \text { pengembangan } \\
& \text { wisata } \\
& \text { \# } \\
& \text { Terdapat tempat } \\
& \text { wisata lain yang } \\
& \text { menjadi pesaing } \\
& \text { \# } \text { Kondisi } \\
& \text { perekonomian } \\
& \text { bangsa yang tidak } \\
& \text { stabil }\end{aligned}$ & $\begin{array}{ll}\text { Strategi S-T } \\
\checkmark \quad \text { Penggalangan dana } \\
\text { mandiri, pemerintah, } \\
\text { dan investasi swasta } \\
\text { untuk pengembangan } \\
\text { wisata } \\
\checkmark \quad \text { Meningkatkan daya } \\
\text { saing obyek wisata } \\
\text { yang berkualitas dan } \\
\text { unik }\end{array}$ & $\begin{aligned} & \text { Strategi W-T } \\
& \checkmark \text { Memperbanyak } \\
& \text { fasilitas pendukung } \\
& \text { wisata } \\
& \checkmark \text { Membuat Promosi } \\
& \text { wisata yang efisien } \\
& \text { dan murah, seperti } \\
& \text { pembuatan webite } \\
& \checkmark \text { Meningkatkan } \\
& \text { pengelolaan } \\
& \text { manajemen wisata }\end{aligned}$ \\
\hline
\end{tabular}

Sumber: Analisis data primer, 2016 
Berdasarkan hasil analis SWOT alternatif strategi yang dibuat dapat diuraikan sebagai berikut:

1. Pengembangan Kampung wayang sebagai tempat wisata minat khusus (wisata budaya, wisata pendidikan)

Saat ini trend wisata minat khusus menjadi daya tarik wisatawan baik lokal maupun mancanegara. Hal ini diperkuat dengan pernyataan Pitana dan Diarta (2009) yang menyatakan bahwa pariwisata minat khusus diperkirakan akan menjadi trend perkembangan pariwisata ke depan sebab calon wisatawan telah menginginkan jenis pariwisata yang fokus, yang mampu memenuhi kebutuhan spesifik wisatawan seperti belajar sambil berwisata. Wisata minat khusus diantaranya adalah wisata budaya ataupun wisata pendidikan. Kampung wayang Kepuhsari berpotensi untuk dijadikan wisata minat khusus baik wisata budaya ataupun wisata pendidikan dengan daya tarik utamanya adalah kesenian tatah sungging wayang. Obyek daya tarik wisata sangat erat hubungannya dengan motivasi berwisata seseorang. Hal ini karena wisatawan ingin mendapatkan pengalaman tertentu dalam kunjungannya sehingga semakin tinggi daya tarik suatu tempat wisata maka semakin tinggi motivasi wisatawan untuk berkunjung (Pitana dan Gayatri, 2005).

2. Pengembangan Paket wisata pendidikan yang efisien

Potensi wisata di Kampung Wayang ini dapat dimungkinkan dapat dikembangkan menjadi wisata pendidikan, diantaranya wisata pendidikan pembuatan wayang ataupun wisata pendidikan pertanian.
Pengelola wisata di Kampung Wayang Kepuhsari diharapkan dapat membuat paket wisata yang efisien sehingga konsumen (wisatawan) akan tertarik untuk melakukan kunjungan wisata. Menurut Simamora (2000), harga merupakan salah satu faktor penting yang mempengaruhi kunjungan wisata. Penentuan harga dalam pemasaran jasa sangat penting menginggat produk yang ditawarkan di Kampung wayang Kepuhsari tidak berwujud dan harga yang dibebankan terhadap jasa yang ditawarkan menjadi indikasi kualitas jasa yang akan diterima konsumen. Terobosan yang dapat diambil untuk menarik minat pengunjung yakni memberikan potongan harga bagi pengunjung, misalnya saja bagi pengunjung yang masih berstatus pelajar mendapatkan potongan harga $10 \%$ karena untuk paket wisata pendidikan ini sasarannya bagi pelajar.

3. Perbaikan aksesibilitas daerah wisata (jalan dan sarana prasarana pendukung lainnya)

Salah satu komponen penunjang wisata adalah aksesibilitas di daerah wisata. Aksesibilitas merupakan unsur penting dalam menganalisa suatu obyek wisata agar dapat dijangkau wisatawan baik dalam segi sarana transportasi. Olehkarena itu diperlukan perbaikan pada aksesibilas di Kampung Wayang diantaranya jalan desa, pembuatan gapura wayang sebagai ikon Kampung wayang maupun sarana prasarana seni tatah sungging guna pengembangan wisata di daerah setempat. Diperlukan suatu upaya bersama yang terintegrasi antara pemerintah daerah dengan pihak terkait yaitu pemerintah desa 
dan pengelola destinasi wisata Kampung Wayang Kepuhsari. Diantaranya keterbatasan dana perbaikan infrastruktur jalan dapat diusulkan dari dana desa sehingga dana pengembangan wisata yang dialokasikan pemerintah daerah dapat digunakan untuk pengembangan sekor wisata lainnya misalnya pengembangan inovasi pariwisata.

4. Meningkatkan Sumber Daya Manusia pelaku usaha wisata (pelatihan pemadu wisata, peran masyarakat dalam kelembagaan).

Sumber Daya Manusia (SDM) merupakan salah satu faktor yang penting dalam memajukan pariwisata. Pentingnya SDM pada sektor pariwisata adalah manusia sebagai faktor kunci dalam mewujudkan keberhasilan kinerja (Evan dalam Setiawan, 2016). Guna pengembangan wisata di Kampung wayang ini maka sangat diperlukan ketrampilan sebagai pemandu wisata yang mana pemandu wisata ini juga harus menguasai bahasa asing utamanya bahasa Inggris karena pengunjung di Kampung wayang tidak hanya dari wisatawan lokal saja namun ada juga dari wisatawan mancanegara. Olehkarena itu perlu adanya pelatihan bahasa asing bagi para pemandu wisata untuk meningkatkan kepuasan pengunjung. Peran masyarakat di Kampung Wayang dalam kelembagaan perlu juga dibenahi dalam hal ini untuk membuka mindset mereka bahwa adanya pengembangan wisata di kampung wayang tidak hanya untuk mensejahterakan kelompok tertentu saja dalam hal ini pengelola, namun dapat mensejahterakan seluruh masyarakat di Kampung wayang sehingga tugas untuk meningkatkan kualitas layanan tidak hanya menjadi tanggungjawab dari pengelola namun dari masyarakatnya juga.

5. Promosi wisata yang kontinyu

Pemasaran pariwisata penekanannya adalah bagaimana mengkomunikasikan kepada pasar (konsumen) bahwa produk yang ditawarkan (destinasi) unggul dan berbeda dengan produk lain. Pengembangan wisata di Kampung wayang salah satunya adalah dengan strategi promosi wisata Kampung wayang yang dapat dilakukan Pemerintah daerah memasang iklan atau promosi melalui surat kabar, radio, majalah lokal ataupun membuat/mengikuti eventevent seni budaya berskala internasional untuk memamerkan keunggulan destinasi wisata di Kampung Wayang Kepuhsari. Selain itu pengelola wisata juga dapat melakukan promosi wisata melalui internet baik itu web, twitter, facebook ataupun instagram tentang destinasi wisata di Kampung Wayang Kepuhsari ini. Diharapkan dengan promosi wisata yang kontinyu akan dapat menarik minat wisatawan untuk berkunjung ke Kampung Wayang Kepuhsari. Hal ini sesuai dengan pernyataan Suwantoro (2004) bahwa salah satu kebijakan pengembangan pariwisata adalah promosi.

6. Penggalangan dana mandiri, pemerintah, dan investasi swasta untuk pengembangan wisata

Salah satu kendala dalam pengembangan wisata di Kampung Wayang Kepuhsari ini adalah keterbatasan dana pengembangan. Solusi dari permasalah ini dapat diatasi dengan penggalangan dana mandiri dan menggandeng pihak swasta untuk 
pengembangan wisata. Dalam hal ini pemerintah juga berperan sebagai penyedia dana pengembangan, namun jika hanya mengandalkan kucuran dana dari pemerintah saja tidak akan optimal bahkan harus menunggu dalam waktu yang relatif lama. Dana mandiri ini dapat diperoleh dari iuran swadaya masyarakat ataupun mencari CSR dari pihak swasta. Pemerintah desa sendiri dalam hal ini Desa Kepuhsari yang memiliki potensi wisata hendaknya mengalokasikan sebagian dari anggaran dana desa bagi pengembangan wisata setempat.

7. Meningkatkan daya saing obyek wisata yang berkualitas dan unik

Salah satu strategi penarik wisatawan mengunjungi obyek wisata adalah adanya keistimewaan atau keunikan yang ditawarkan suatu tempat wisata. Menurut Yoeti (2002), daya tarik daerah tujuan wisata harus memiliki 3 kriteria agar dapat diminati pengunjung, yakni something to see, something to do dan something to buy. Daya tarik yang ada di Kampung wayang Kepuhsari ini sudah menenuhi kriteria tersebut. Something to see, daya tarik Kampung wayang diantaranya seni tatah sungging (pembuatan wayang), seni lukis kaca, seni menabuh gamelan, air terjun Banyu Nibo. Something to do, wisatawan dapat melakukan berbagai aktivitas di Kampung wayang Kepuhsari diantaranya wisatawan dapat belajar membuat wayang (seni tatah sungging), menikmati pertunjukan wayang kulit, menikmati keindahan alam di air terjun dan sebagainya. Something to buy, di Kampung wayang Kepuhsari terdapat toko souvenir yang menjual pernak pernik yang mencerminkan kampung wayang diantaranya wayang kulit, lukis kaca, gantungan kunci dan baju yang bertema wayang, dan sebagainya. Disamping itu masyarakat maupun pengelola wisata disarankan untuk meningkatkan pelayanan dan keramah tamahan terhadap pengunjung agar mereka merasa terkesan sehingga dapat menikmati kepuasan berwisata bahkan mengulang kembali untuk berwisata ke Kampung wayang Kepuhsari.

8. Peningkatan Manajemen Pengelolaan wisata

Pengelolaan daerah tujuan wisata membutuhkan peran pemerintah yang juga melibatkan masyarakat sebagai upaya peningkatan ekonomi masyarakat. Manajemen pengelolaan pariwisata yang melibatkan peran masyarakat ini dinamakan Community Based Tourism (CBT). Wisata Kampung wayang Kepuhsari ini pengelolaannya oleh Kelompok Sadar Wisata (Pokdarwis) yang anggotanya berasal dari masyarakat di Desa Kepuhsari atas pembinaan dari pemerintah daerah Kabupaten Wonogiri. Salah satu strategi dalam manajemen pengelolaan wisata yang dapat dilakukan oleh pengelola adalah membuat paket wisata yang efisien. Dukungan pemerintah daerah dalam pengelolaan wisata di Kampung wayang dintaranya melakukan pembinaan, pelatihan dan pengawasan. Kebijakan pengembangan pariwisata daerah di Kabupaten Wonogiri, khususnya di Kampung Wayang Kepuhsari dilakukan melalui penerapan beberapa program, misalnya saja pembinaan pokdarwis (kelompok sadar wisata), 
kegiatan roadshow promosi paket wisata, pembinaan kepada pemilik homestay, dsb.

Dilihat dari hasil analisis SWOT kondisi eksisting kawasan wisata Kampung wayang Kepuhsari saat ini walaupun masih memiliki kelemahan dan ancaman dalam usaha pengembangannya, namun dengan adanya kekuatan dan peluang yang muncul maka kelemahan dan ancaman dapat diantisipasi dan dieliminasi dampaknya. Oleh karena itu strategistrategi yang telah dirumuskan diatas dapat dijadikan sebagai dasar pengembangan wisata Kampung Wayang Kepuhsari. Pembangunan wisata di kampung wayang ini menjadikan multiplier effect yang luas bagi perekonomian masyarakat sekitar maupun bagi pemerintah daerah. Bagi masyarakat di Desa Kepuhsari menjadi sumber lapangan pekerjaan diantaranya usaha kuliner, souvenir, pemandu wisata, hotel/homestay dan jasa lainnya. Bagi pemerintah daerah kontribusi adanya obyek wisata di kampung wayang ini berupa pajak pendapatan wisata yang akan menjadi sumber pendapatan asli daerah.

\section{PENUTUP}

\subsection{Kesimpulan}

Rumusan Strategi pengembangan wisata di Kampung Wayang Kepuhsari setelah dilakukan analisis SWOT antara lain Pengembangan Kampung Wayang sebagai tempat wisata minat khusus (wisata budaya, wisata pendidikan); Pengembangan Paket wisata pendidikan yang efisien; Perbaikan aksesibilitas daerah wisata (jalan dan sarana prasarana pendukung lainnya); Meningkatkan SDM pelaku usaha wisata (pelatihan pemadu wisata, peran masyarakat dalam kelembagaan); Penggalangan dana mandiri, pemerintah, dan investasi swasta untuk pengembangan wisata; Promosi wisata yang kontinyu; meningkatkan daya saing obyek wisata yang berkualitas dan unik serta peningkatan manajemen pengelolaan wisata.

\subsection{Saran}

Beberapa saran yang dapat disampaikan dalam penelitian ini diantaranya sebagai berkut:

1. Kerjasama yang saling terintegrasi antara pihak pemerintah, pengelola wisata dan desa sehingga pengembangan kampung wayang sebagai daerah wisata semakin optimal.

2. Pengembangan wisata minat khusus, seperti wisata pendidikan dan wisata budaya hendaknya ditingkatkan karena saat ini trend wisata minat khusus banyak dicari oleh wisatawan. Melalui pengembangan wisata minat khusus di Kampung Wayang Kepuhsari diharapkan memberi dampak positif bagi masyarakat maupun pemerintah daerah Kabupaten Wonogiri karena pengembangan wisata minat khusus di Kabupaten Wonogiri masih jarang, sehingga ini dapat menjadi terobosan baru dalam pengembanganpariwisata khususnya di Kabupaten Wonogiri. 


\section{DAFTAR PUSTAKA}

Amirullah. 2004. Manajemen Strategik. Graha Ilmu: Yogyakarta.

Arsyad, Lincolin.1999. Ekonomi Pembangunan. Yogyakarta: STIE YKPN.

Arsyadha, Gita, Alfa. 2002. Identifikasi Potensi Wisata Kepulauan Karimunjawa Sebagai Pemasukan Penentuan Prioritas Komponen Pendukung Pengembangan Pariwisata. Jurusan Perencanaan Wilayah dan Kota fakultas Teknik. Semarang: Universitas Diponegoro.

Demartoto, A. 2009. Pembangunan Pariwisata Berbasis Masyarakat. Surakarta: Sebelas Maret University Press.

Pitana, I Gede dan Diarta,I.K. 2009. Pengantar Pariwisata. Yogyakarta: Penerbit Andi.

Pitana, I Gede dan Gayatri, P.G. 2005. Sosiologi Pariwisata. Yogyakarta: Penerbit Andi.

Poerwadarminta. 2002. Kamus Besar Bahasa Indonesia. Jakarta: Balai Pustaka.

Tjiptono, F. 2002. Manajemen Jasa. Yogyakarta: ANDI.

Rangkuti. 2005. Analisis SWOT: Teknik Membedah Kasus Bisnis. Jakarta: PT. Gramedia.

Salusu, J. 2003. Pengambilan Keputusan Stratedjik Untuk Organisasi Publik dan Non Profit. Jakarta: PT. Gramedia Grasindo.

Setiawan, R.I. 2016. Pengembangan Sumber Daya Manusia di Bidang Pariwisata: Perspektif Potensi Wisata Daerah Berkembang. Jurnal Penelitian Manajemen Terapan Vol 1. Nomor 1. Hal 23-35.

Simamora, H.2000. Akutansi Bisnis Pengambilan Keputusan Bisnis. Jakarta: Salemba Empat.

Suwantaro, G. 2004. Dasar-dasar Pariwisata. Jogjakarta: ANDI.

Yoeti, O.A. 2002. Perencanaan Strategis Pemasaran Daerah Tujuan Wisata. Jakarta: Pradnya Paramitha.

Undang-Undang No. 10 tahun 1999 Tentang Kepariwisataan. 